Psihologijske teme, 27 (2018), 3, 437-452

Izvorni znanstveni rad - UDK - 159.91

159.95

doi:https://doi.org/10.31820/pt.27.3.5

\title{
Linear Representation of Pitch Height in the SMARC Effect
}

\author{
Valter Prpic \\ De Montfort University, Faculty of Health and Life Sciences, \\ Institute for Psychological Science, United Kingdom \\ Dražen Domijan \\ University of Rijeka, Faculty of Humanities and Social Sciences, \\ Department of Psychology, Croatia
}

\begin{abstract}
The Spatial-Musical Association of Response Codes (SMARC) effect consists in faster and more accurate responses to low (vs. high) pitched tones when they are executed in the bottom/left (vs. top/right) space. This phenomenon has many similarities with the Spatial-Numerical Association of Response Codes (SNARC) effect which, however, has been more extensively investigated and theoretically debated. The first theoretical account of the SNARC effect suggests the existence of a direct mapping between the position of a number on a mental number line and the external space of response execution. Conversely, following accounts claim that numbers are automatically categorized in two opposing categories (e.g., small vs. large) and then associated to response alternatives (left vs. right). A modified task, consisting in unimanual close/far responses relative to a reference key, has been employed to disentangle between the opposite theoretical accounts of the SNARC effect. However, this modified task has never been applied to pitch height and currently there are no specific theoretical accounts for the SMARC effect. The aim of this study is to fill this gap of knowledge. Contrary to what has been found for numbers, our data are more in line with the "direct mapping" account and suggests a linear representation of pitch height. Our data suggest that SNARC and SMARC effects might have different origins and might require different theoretical accounts.
\end{abstract}

Keywords: SMARC, SNARC, pitch height, spatial response compatibility, mental number line

$\triangle$ Valter Prpic, Institute for Psychological Science, Faculty of Health and Life Sciences, De Montfort University, The Newarke, UK. E-mail: valter.prpic@dmu.ac.uk 


\section{Introduction}

A special relationship seems to link music, numbers and space. This relationship is quite well known since ancient times, and modern research has shown that both pitch height and number magnitude are similarly associated with spatial coordinates. The Spatial-Musical Association of Response Codes (SMARC) effect (Rusconi, Kwan, Giordano, Umiltà, \& Butterworth, 2006) showed low (vs. high) pitched tones to be associated with the bottom/left (vs. top/right) space. Similarly, the SpatialNumerical Association of Response Codes (SNARC) effect (Dehaene, Bossini, \& Giraux, 1993) showed small (vs. large) numbers to be associated with the left (vs. right) space. Although the nature of the SNARC effect is still highly debated, different theoretical accounts have been formulated and extensive literature has been dedicated to this phenomenon. Conversely, little is known about the nature of the SMARC effect and, to the best of our knowledge, an independent attempt to account for this effect has never been made. Therefore, whether the SMARC and SNARC effects are two independent phenomena or the results of a more general phenomenon is still unclear. In order to address this question, the predictions of the theoretical accounts of the SNARC effect should be tested by using pitch height instead of numbers.

In the SNARC effect, participants generally respond faster with the left-hand side to relatively small numbers and with the right-hand side for relatively large numbers when a parity judgment is required (Dehaene et al., 1993). Indeed, even when magnitude information is irrelevant for performing the task, an association between number magnitude and response position is observed. Dehaene et al. (1993) explained such evidence suggesting that, during parity judgments of Arabic digits, a representation of number magnitude is accessed in an automatic way. As stated by the authors, this representation may be connected to a spatially oriented mental number line (Restle, 1970), where small numbers are allocated in the left space and large numbers in the right space. Therefore, the SNARC effect would be the result of a direct correspondence between this mental representation and the execution of responses in the external space. Santens and Gevers (2008) named this theory the "direct mapping" account.

However, Santens and Gevers (2008) strongly opposed the direct mapping account, suggesting a different interpretation of Dehaene et al.'s (1993) results. Indeed, they supported two alternative accounts, called "intermediate coding" accounts, which do not imply a mental number line for explaining the SNARC effect. The first one (Gevers, Verguts, Reynvoet, Caessens, \& Fias, 2006) assumes a three layer model in which: the bottom layer corresponds to number representation, the middle layer attributes numbers in conceptual categories depending on task requests (e.g., small/large, odd/even) and the upper level represents response alternatives. In a subsequent conceptual update (Notebaert, Gevers, Verguts, \& Fias, 2006), an abstract spatial code has been added to the model. Therefore, the categorical 
representations provided by the middle layer activate an abstract spatial code (e.g., left or right) before activating the response. Categorical representations, such as small/large or odd/even, are then associated with response alternatives (e.g., left/right). The second account, originally proposed by Proctor and Cho (2006), suggests that stimuli and responses are both coded at an intermediate level as negative (-) or positive (+) polarities. This account, also called "polarity correspondence principle", extends to a great variety of tasks and stimuli that can be coded on a bipolar dimension; not only to numbers. Both "intermediate coding" accounts state that numbers are coded as either small or large before the activation of a spatial response and, at a later stage, this magnitude representation is associated with the corresponding response alternatives.

According to these different accounts, the SNARC effect can be either of visuospatial nature ("direct mapping" account) or of verbal-spatial nature ("intermediate coding" accounts). Several studies (Gevers et al., 2010; Leth-Steensen, \& Citta, 2016; Santens, \& Gevers, 2008; Santiago, \& Lakens, 2015) aimed to address this issue and to provide evidence in favor of one account or to the other. However, no conclusive evidence was provided so far and the question remains unsettled. In our opinion, one of the most interesting attempts to disambiguate between the "direct mapping" account and the "intermediate coding" accounts was made by Santens and Gevers (2008). These authors proposed a modified response mapping in a numerical comparison task. The experiment was designed to establish a spatial-numerical association to close and far responses, independently from left and right coordinates. Participants had to judge whether a given number $(1,4,6$, or 9$)$ was smaller or larger than a middle reference (5). They had to move their right index finger to a close or far location on a QWERTY computer keyboard. Half of the participants responded moving to the left side of the keyboard ("h" key for close and "g" key for far responses) while the other half responded moving to the right side ("k" key for close and "l" key for far responses). Every movement started from the middle key " $\mathrm{j}$ " and responses were thus labeled as being close or far from that key.

As stated by the authors, the "direct mapping" account predicts an advantage for close responses when responding to numbers close to the middle reference standard (5) on the mental number line (4 and 6), while an advantage is expected for far responses to numbers far from the middle reference on the mental number line ( 1 and 9). Therefore, a direct mapping is expected between the numerical distance on the mental number line ( 4 and $6=$ close; 1 and $9=$ far) and the physical distance of external responses. On the other hand, the intermediate coding accounts predict that numbers are coded as smaller or larger than a middle reference standard (5) before the activation of a spatial response. Therefore, 1 and 4 (small numbers) should be associated with close responses, while 6 and 9 (large numbers) with far responses. An interaction is thus expected between the relative magnitude of a number (small/large) and the location of the response (close/far) without any connection to a spatial mental representation, such as the mental number line. 
Results provided by Santens and Gevers (2008) corroborate the latest prediction, showing faster close responses to small numbers ( 1 and 4$)$ and faster far responses to large numbers (6 and 9). No effect of moving direction was provided, showing that participants were equally fast in responding to the left or to the right side of the middle key. This evidence argues in favor of the "intermediate coding" accounts, showing that a spatially oriented number line is not needed for explaining the SNARC effect.

By using a similar paradigm to that introduced by Santens and Gevers (2008), Antoine and Gevers (2016) firstly demonstrated that numerical magnitude associates with close/far responses even when magnitude is irrelevant to the task. This evidence seems to further support the "intermediate coding" accounts, and to oppose the idea that the SNARC effect is caused by a direct correspondence between the position of numbers on the mental number line and the external space of response execution. The results provided by Antoine and Gevers (2016) are important because they finally revealed that the association between numbers and close/far responses is automatic and flexible, namely, that it has the same characteristics of the SNARC effect.

The last two decades of research on the SNARC effect revealed that not only numbers but also many other ordinal or magnitude related stimuli can be spatially organized. Some examples are: letters of the alphabet and months of the year (Gevers, Reynvoet, \& Fias, 2003), physical size (Ren, Nicholls, Ma, \& Chen, 2011), luminance (Fumarola et al., 2014; Ren et al., 2011) and angle magnitude (Fumarola et al., 2016). Furthermore, a noteworthy subgroup of research related to the SNARC effect focused on the relationship between musical stimuli and space, revealing many similarities in the representation of numbers and musical parameters. Indeed, both temporal (music tempo, Prpic, Fumarola, De Tommaso, Baldassi, \& Agostini, 2013; musical note values, Prpic, Fumarola et al., 2016; Prpic, 2017) and tonal (pitch height, Lidji, Kolinsky, Lochy, \& Morais, 2007; Rusconi et al., 2006) aspects of a sound showed to be strictly linked with space.

Particularly relevant for our study is the work of Rusconi et al. (2006), which employed classical SNARC-like tasks and found that pitch height has a similar mental representation as numbers do (for some rudiments of music theory on pitch height see Prpic, Murgia et al., 2016). These authors called this effect Spatial-Musical Association of Response Codes. In Experiment 1, musically untrained participants performed a pitch comparison task in which two pure tones had to be compared. Participants responded both with horizontal (left/right key-presses) and vertical (down/up key-presses) response alignments, showing a significant SNARC-like effect for both response mappings, with a clear up/right and down/left response advantage for high- and low-frequency pitches, respectively. In Experiment 2, nonmusicians had to classify relatively high and low pitched sounds as being produced by wind or percussion instruments. In this task, commonly named the timbre judgment task, the direct comparison of the pitch height of the stimuli is not required 
and therefore it more closely resembles the parity judgment task used in the SNARC effect. Results showed an advantage for up key-press responses with high pitched tones and for down key-press responses with low pitched tones, while there was no evidence for such association in the horizontal alignment. Note that, even for the vertical alignment, the SMARC effect was revealed only for large tone distances (4 tones distance from the implicit reference) while intermediate pitches did not show a reliable association with the space of response execution. In Experiment 3, musically trained participants performed the same timbre judgment task, showing both a vertical and horizontal SMARC effect. This evidence suggests that, similarly to numbers, pitch height can be mapped into space even when it is completely task irrelevant (i.e., during a timbre judgment task). Furthermore, Rusconi et al. (2006) show that music expertise is an important factor, as non-musicians are less prone to process musical stimuli and, consequently, to map them into spatial coordinates.

Lidji et al. (2007) confirmed the findings of Rusconi et al. (2006) by using synthesized tones, with piano and violin timbre, instead of pure tones. Moreover, authors extended the study also to the contour of melodic intervals, showing, however, very limited evidence of a spatial association. The only reliable result of this association was found for the musicians group when performing a timbre judgment with horizontally aligned responses. Indeed, an association was assessed between descending/ascending contour intervals and left/right key-press responses, respectively. Lidji et al. (2007) suggest that the "piano in the head" could be a culturally supplied spatial representation for musical stimuli, such as the "mental number line" is commonly used as a metaphor for number representation. Taken together, these studies suggest that musical pitches and numbers share similar spatial representations and can produce comparable spatial-response correspondence effects, such as the SNARC and the SMARC effects.

The aim of the present study is to assess whether the spatial association for pitch height fits one of the predictions resulting from the main opposite accounts proposed to explain the SNARC effect, namely, the "intermediate coding" (Gevers et al., 2006; Proctor, \& Cho, 2006) and the "direct mapping" (Dehaene et al., 1993) accounts. To do so, we applied the modified SNARC paradigm introduced by Santens and Gevers (2008) to musical pitches. Instead of four numbers $(1,4,6,9)$ we used four pitches (E2, C\#4, D\#5, C7) with equivalent distance ratio of the stimuli used by Santens and Gevers (2008). As a distance unit we used a perfect fifth interval, which consists in seven semitones on the chromatic scale. Differently from these authors, but similarly to Antoine and Gevers (2016), we used a task in which a direct comparison of the stimuli is not required (i.e., timbre judgment). Indeed, this kind of task can be considered more informative about the automaticity of a spatial association, and avoid the risk to obtain results as an artifact induced by task instructions.

According to the "intermediate coding" accounts, relatively low pitched frequencies (E2, C\#4) should be associated with close responses and high pitched frequencies (D\#5, C7) with far responses. Conversely, according to the "direct 
mapping" account, pitch height should follow a spatially oriented mental line representation, as proposed by Lidji et al. (2007) with the "piano in the head" metaphor. Therefore, pitches with middle range frequencies (C\#4, D\#5) should be associated with close key-press responses, while pitches with frequencies far from the middle range (E2, C7) should be associated with far key-press responses.

Nevertheless, it is worth noting that the predictions originated from the two accounts are partially overlapping. Indeed, the highest pitch (C7) is always associated with far key-press responses in both the accounts, while the relatively low pitch with middle range frequency $(\mathrm{C \# 4})$ is always associated with close key-press responses in both the accounts (Table 1). Therefore, we restricted our predictions only to the stimuli that allowed us to disambiguate between opposite accounts, namely, the lowest pitch (i.e., E2) and the relatively high pitch with middle range frequency (i.e., D\#5). Therefore, evidence of an association between E2 and close responses, and between D\#5 and far responses would support the "intermediate coding" accounts as the explanation for the spatial association for pitch height (i.e., the SMARC effect). Conversely, evidence of an association between E2 and far responses, and between D\#5 and close responses would support the "direct mapping" account, suggesting a linear representation for pitch height.

Table 1

Predictions for the SMARC Effect with Close/Far Responses

\begin{tabular}{lcc}
\hline Responses & $\begin{array}{c}\text { Direct mapping } \\
\text { account }\end{array}$ & $\begin{array}{c}\text { Intermediate coding } \\
\text { accounts }\end{array}$ \\
\hline Close & D\#5; C\#4 & E2; C\#4 \\
Far & E2; C7 & D\#5; C7 \\
\hline
\end{tabular}

\section{Method}

\section{Participants}

Twenty-two musicians with formal musical education took part in the experiment. Half of them were male (mean age: 25 , range: 19-32) and the other half were female (mean age: 25 , range: 19-36). They played different musical instruments ( 1 clarinet, 1 flute, 1 percussion, 4 guitar, 1 harpsichord, 1 oboe, 6 piano, 7 violin) with a mean of 14 years of practice among formal and informal studies. All of them attended courses and passed exams at a conservatory. Informed consent was obtained prior to participation in the experiment, which was conducted in accordance with the ethical standards established by the Declaration of Helsinki. 


\section{Apparatus and Stimuli}

The experiment was created and controlled by means of the E-Prime software, version 2.0. Audio stimuli were presented through a couple of AKG professional hifi stereo studio headphones. The PC was a Dell notebook with Intel Core i3 (RAM: $2 \mathrm{~Gb}$ ). The Operating System was Windows 7 64-bit Edition. A nine key usb DirectIN Button-Box was used for collecting responses. Only five of the response keys were used - key numbers 2, 4, 5, 6, and 8 .

Stimuli consisted of four pitched tones with different height values (E2, C\#4, D\#5, and C7). Stimuli were created with the perfect fifth interval (7 semitones) as a distance unit, thus, three perfect fifth intervals (21 semitones) separate E2 from C\#4 and D\#5 from C7, while two perfect fifth intervals (14 semitones) separate C\#4 from D\#5. The distance ratio between stimuli mirrors the one used by Santens and Gevers (2008) in their study (i.e., from 1 to $4=3$ units, from 4 to $6=2$ units, and from 6 to $9=3$ units) (Figure 1). Half of the pitched tones were presented with a synthesized violin timbre sound and the other half with a synthesized grand piano timbre sound. These instruments were selected, according to previous literature (Lidji et al., 2007), because of their clearly distinguishable timbre sounds.

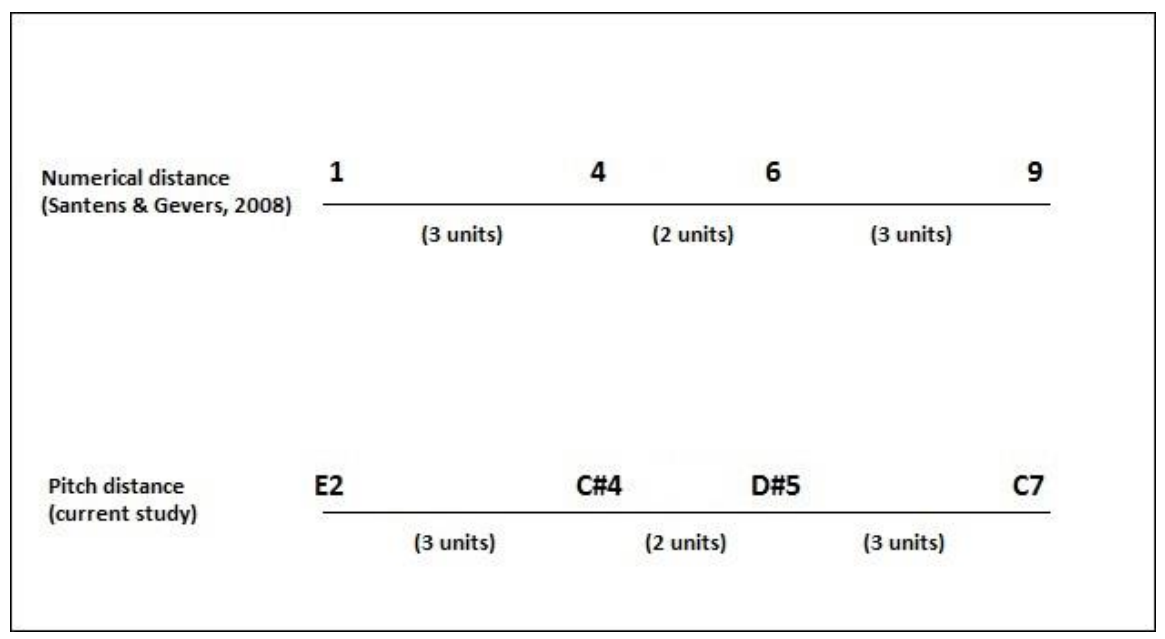

Figure 1. Linearly represented stimuli's distance for numbers (Santens \& Gevers, 2008) and pitches (current study).

\section{Procedure}

The experiment took place in a quiet, dimly lit room without environmental distractions. Participants were positioned in front of the PC at an approximated distance of $50 \mathrm{~cm}$ from the screen. The midlines of the screen and the response box were aligned with the midline of the participant's body. 
Each trial started with a 1000ms fixation cross, then a hash mark (\#) appeared at fixation until participants pressed the middle key (key number 5) with their right index finger. As soon as this key was pressed, a target pitched tone was presented through the headphones and participants had to decide whether the timbre of the pitch was a violin or piano sound. In one block, if the timbre corresponded to a violin sound, participants had to move their finger and press the close response key. Conversely, if the timbre corresponded to a piano sound they had to move their finger and press the far key. In the other block, the timbre/response-key mapping was reversed (i.e., violin timbre/far key-press; piano timbre/close key-press). The response mapping was manipulated within subjects and the order of the two blocks was counterbalanced over participants. The moving direction was manipulated between subjects; half of the participants always moved their finger to the left (close key number 4; far key number 2) and the other half to the right (close key number 6; far key number 8). All the participants used only the right index finger to provide responses and the movements were always executed starting from the middle key to the target keys. After the response, a 500ms inter-trial interval (ITI) appeared before the whole sequence started again. There were two blocks of 64 trials, thus, each target pitch was repeated 16 times per block ( 8 with violin and 8 with piano timbre sound). The order of presentation of the target stimuli was randomized in every block. Each of the two sessions started with 8 training trials with accuracy feedback, to adapt participants to the correct response mapping. Participants were allowed to take a short break between the two sessions if needed, otherwise they continued with the experiment. Response keys were labeled in the instructions as being close or far from the middle key. No reference to small or large movements, left or right directions, and response key number was made. Both speed and accuracy of the target response were stressed in the instructions, while no specific instructions were given for the middle key pressing and releasing speed.

\section{Results}

Participants made just a few errors (1.9\% of all trials) so it was not possible to conduct analysis on accuracy rates.

Only correct trials were included in the Response Times (RTs) analysis. Moreover, RTs slower than $200 \mathrm{~ms}(0 \%)$ and faster than $1000 \mathrm{~ms}(2.6 \%)$ were excluded from the analysis. A mixed ANOVA was run with a 2 (movement direction: left/right) by 2 (instrument timbre: piano/violin) by 2 (responses location: close/far) by 4 (pitch height: E2, C\#4, D\#5, C7) design. Movement direction was treated as a between-subjects variable, while instrument timbre, response location and pitch height were treated as within-subjects variables. There was a main effect of the instrument timbre, $F(1,20)=8.37, p<.01$, meaning that piano and violin timbre sounds were not equally easy to judge. A main effect of the response location was observed, $F(1,20)=103.26, p<.001$, showing that responses to a physically 
close key were executed faster (597 ms) than responses to a far key $(639 \mathrm{~ms})$. There was also a main effect of pitch height, $F(3,60)=15.86, p<.001$, but no interactions between pitch and movement direction, $F(3,60)=.59, p=.622$, showing that there was no influence of pitch height to the movement direction (left/right). More importantly, the interaction between pitch height and response location reached significance, $F(3,60)=2.94, p<.05$. Furthermore, there was a significant three-way interaction between pitch height, response location and movement direction, $F(3,60)$ $=4.05, p<.05$. All the other interactions were non-significant, $F s<3.35, p s>.059$.

The main effect of instrument timbres suggested providing separate analyses for violin and piano stimuli. Therefore, a mixed ANOVA was run with a 2 (movement direction: left/right) by 2 (responses location: close/far) by 4 (pitch height: E2, C\#4, D\#5, C7) design for both violin and piano timbre sounds. Only piano showed a significant interaction between pitch height and response location, $F(3,60)=3.42, p$ $<.05$ (Figure 2), while there was no interaction for violin stimuli, $F(3,60)=0.75, p$ $=.52$. However, a three-way interaction between pitch height, response location and movement direction reached significance for violin timbre sounds, $F(3,63)=3.93$, $p<.05$. This evidence suggests that movement direction can influence the interaction between pitch height and response location with violin stimuli. Therefore, we provided separate analysis for left and right movement directions with violin timbre sounds. For the sake of completeness we reported here all the remaining main effects and interactions showed for both piano [response location, $F(1,20)=8.32, p<.01$; pitch height, $F(3,60)=3.17, p<.05$; the remaining two-way interactions and a threeway interaction were non-significant, $F s<1.5, p s>.2$ ] and violin [response location, $F(1,20)=9.8, p<.01$; pitch height, $F(3,60)=12.64, p<.001$; the remaining twoway interactions were non-significant, $F s<2.51, p s>.13$ ] timbre sounds.

A repeated measures ANOVA was run with a 2 (responses location: close/far) by 4 (pitch height: E2, C\#4, D\#5, C7) design for both left and right movement directions with violin timbre sound. For the left movement direction, the interaction between pitch height and response location reached significance $F(3,30)=4.30, p<$ .05 (Figure 3), while there was no interaction for right movement direction $F(3,30)$ $=0.78, p=.52$. For the sake of completeness we reported here the remaining main effects for both left [response location, $F(1,10)=9.8, p<.05$; pitch height, $F(3,30)$ $=5.24, p<.01]$ and right [response location, $F(1,10)=1.38, p>.267$; pitch height, $F(3,30)=7.69, p<.01]$ movement direction.

To test our hypothesis we performed the Fischer LSD tests of difference in observed cell means for the predictor pitches (i.e., E2 and D\#5). For piano tones, the test showed no difference between far responses, while there was a largely significant difference between E2 $(615 \mathrm{~ms})$ and D\#5 $(569 \mathrm{~ms})$ for close responses $(p<.001)$ (Figure 2). Similarly, for left movement direction with violin timbre sounds, the test showed no difference between far responses, while there was a largely significant difference between E2 $(623 \mathrm{~ms})$ and D\#5 $(540 \mathrm{~ms})$ for close responses $(p<.001)$ (Figure 3). 


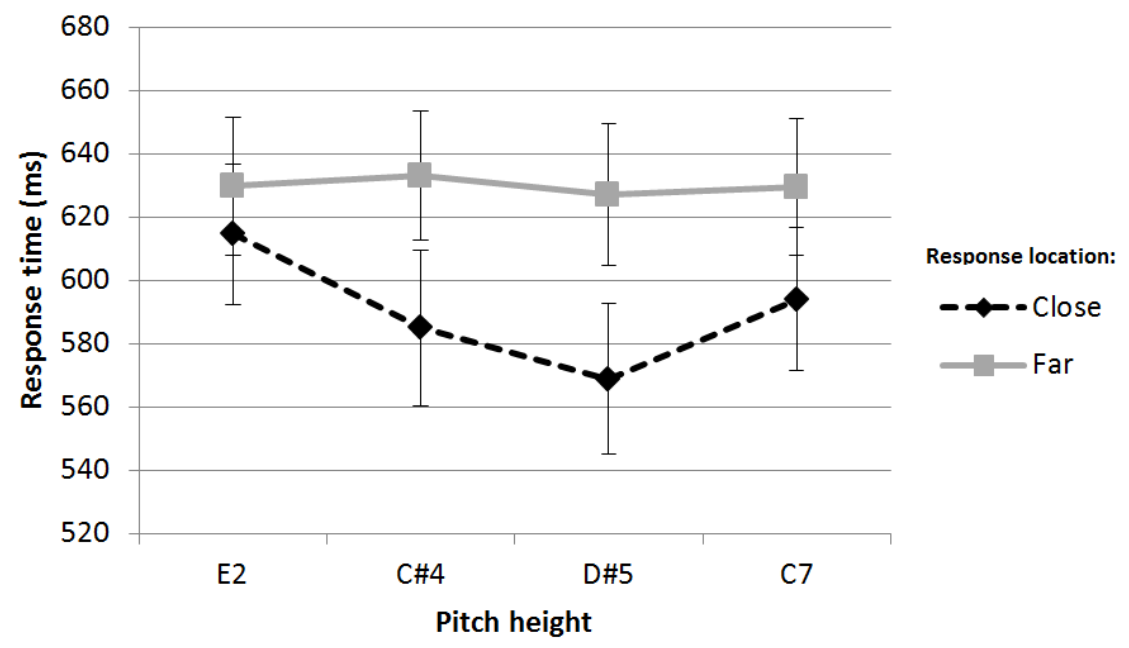

Figure 2. Mean response times with close/far response keys for pitches with piano timbre sounds. Error bars represent SEM.

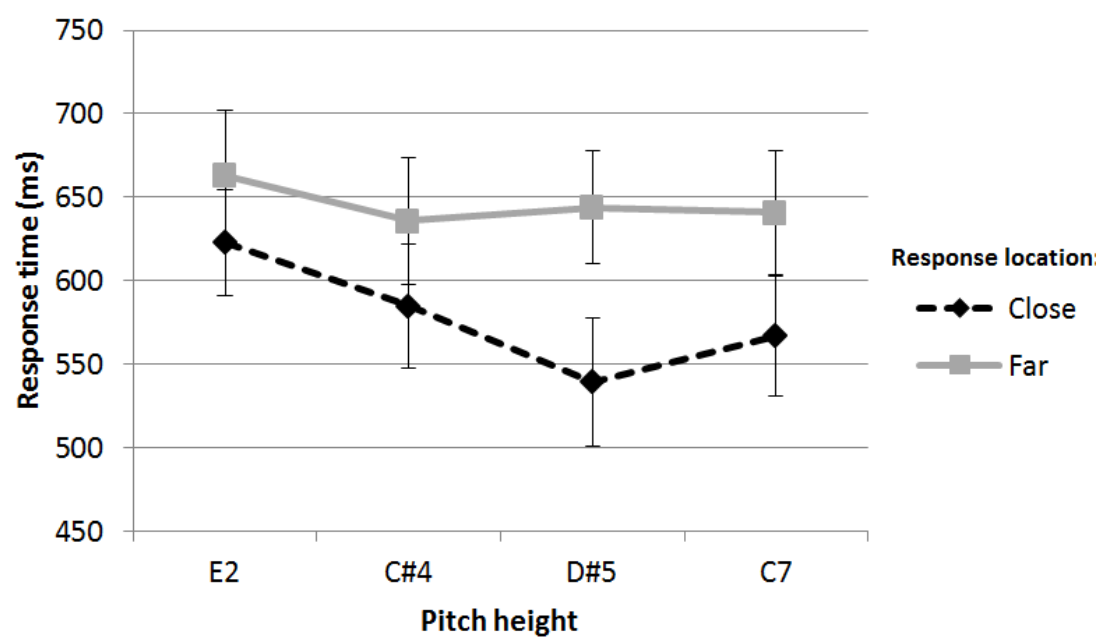

Figure 3. Mean response times with close/far response keys for pitches with violin timbre sounds and left movement direction. Error bars represent SEM. 


\section{Discussion}

The existence of a special relationship between music, numbers and space has been well known since ancient times. A powerful example of the coupling between these dimensions is represented by the sound produced in proportion to the string lengths (i.e., the shorter the length of the string, the higher the pitch of the sound, and vice versa). The Greeks first expressed these relations mathematically and by doing this they established the basics of modern day musical notation. Furthermore, these three dimensions seem to be somehow interchangeable and our cognitive system seems to process them in a very similar way. For instance, if we consider some illusions of numerosity, such as the solitaire illusion (Frith \& Frith, 1972), the misjudgment of the number of elements can be similarly elicited by the spatial separation of these elements or by the distance in pitch height (Prpic \& Luccio, 2016). Similarly, as the SNARC effect (Dehaene et al., 1993) is considered an example of the coupling between numbers and space, the SMARC effect (Rusconi et al., 2006) can be considered evidence of the relationship between pitch height and space.

The present study was designed to investigate whether the spatial association for pitch height, also known as the SMARC effect, better fits the predictions of the "intermediate coding" accounts (Gevers et al., 2006; Proctor \& Cho, 2006) or of the "direct mapping" account (Dehaene et al., 1993).

In the numerical domain, Santens and Gevers (2008) published an innovative study that breaks with the idea that a mental number line is needed to account for the SNARC effect. Using a number magnitude comparison task, these authors showed evidence supporting the "intermediate coding" accounts and opposing to the "direct mapping" account. Indeed, numbers close (4 and 6) and far (1 and 9) from the reference standard (5) on the mental number line were not associated with physically close/far response key-presses, respectively, as the "direct mapping" account predicts. Conversely, small ( 1 and 4$)$ and large (6 and 9) number magnitudes were associated with close/far response key-presses, respectively. This evidence suggests that numerical stimuli are coded at an intermediate coding level as large (+) and small $(-)$, and subsequently associated with response alternatives.

In the present study, we introduced the same spatial coding (close/far responses) proposed by Santens and Gevers (2008) by using musical tones with different pitch frequencies. Similarly to a following study by Antoine and Gevers (2016), we used a task in which the direct comparison of the stimuli was not required (i.e., a timbre judgment task). This kind of task is considered more informative about the automaticity of spatial associations. Indeed, it avoids the risk of obtaining results as an artifact induced by task instructions. A convenience sample of musicians playing different instruments was used in this study since previous evidence showed that a left-to-right representation of musical tones, although stronger in piano players after performing on the piano, is shared also by musicians (i.e., flute players) playing an instrument with opposite tone mapping (Timmers \& Li, 2016). Therefore, given the 
universality of this representation, we assumed that all the participants in our study shared the same response mapping for pitch height.

Our results show a different pattern from that revealed in the numerical domain. Indeed, they suggest middle range frequency pitches (C\#4 and D\#5) to be associated with physically close responses, and non-middle range frequency pitches (E2 and C7) to be associated with physically far responses. More specifically, our predictions were restricted to two pitches (E2 and D\#5), since they are the only two stimuli that can allow us to disambiguate between the predictions of the "intermediate coding" and "direct mapping" accounts. Conversely, the other two stimuli (C\#4 and C7) were not considered in our study, since both the accounts predict them to be associated with close/far responses, respectively (see Table 1).

For both piano (left and right movement directions) and violin (left movement direction) timbre sounds, close responses were clearly faster for D\#5 and slower for E2, as supported by the "direct mapping" account. Conversely, this evidence is in contrast with the predictions of the "intermediate coding" accounts. However, only close responses showed this pattern while there was no reliable difference between far responses. The response pattern revealed for far responses may be explained by a ceiling effect, since far response mapping required participants to move their finger to a physically far response key, and this caused far responses to be overall significantly slower than close responses. These longer response latencies may thus have been masked evidence of the spatial associations for pitch height with far responses. Furthermore, when responses were executed for the violin timbre sound with right movement direction, no associations with close/far responses seemed to emerge. This evidence remains quite unclear, even though we could propose some speculative hypothesis based on the timbre sounds of the stimuli and the related instruments' structures.

Indeed, the piano keyboard is centered from the musician's perspective, so that pitches are equally represented in the left/right side of space. Thus, no preference for left/right mapping can be expected for piano tones. Moreover, the horizontally displayed response keys used in the experiment were highly compatible with the piano keyboard structure. It is possible that the interaction between pitch and response location is enhanced when the representation of pitches overlaps with the external response mapping. Conversely, given the sagittal plane of the musician's body, violin pitches are all represented in the left side of space (at least in right handed musicians) because the instrument is exclusively played in the left hemispace. Thus, differently from piano timbre, violin stimuli could show a preferential mapping for the left side of space and the spatial association for violin timbre pitches could go missing when movements are executed in the right side of space.

A limitation of the present study is that we have restricted sample size and we might lack statistical power to test three- and four-way ANOVAs and three-way interactions. Indeed, a larger sample size would be recommended for further studies 
aiming at replicating these findings. Although previous research suggested that the spatial representation of pitch height is universal through musicians playing instruments with different tone arrangements (Timmers \& $\mathrm{Li}, 2016$ ), the use of more homogenous groups of musicians would be useful to remove a possible confounding variable. Furthermore, a comparison of two groups of musicians playing instruments with opposite tone arrangements (i.e., flute and piano) would be useful to further test the universality of the left-to-right representation of pitch height.

Overall, our results support the idea that pitch height is linearly represented along a continuous, analogical, mental representation. This representation is in line with the "piano in the head" metaphor proposed by Lidji et al. (2007), and seem to share common properties with the mental number line (Restle, 1970). Therefore, the origin of the SMARC effect is more likely to be of visuo-spatial nature and the direct mapping account seems to be the main explanation for such phenomenon. Conversely, the spatial association in the numerical domain seems to better fit the "intermediate coding" accounts and, therefore, its foundation seems more likely to be of verbal-spatial nature. From this point of view, numbers and musical pitches seem to be largely dissimilar, supporting respectively opposite theoretical accounts.

\section{Acknowledgments}

We are grateful to the State Conservatory of Music "Jacopo Tomadini", Udine (Italy), for letting us test their students and use the Conservatory's facilities. Special thanks goes to Annamaria Brusaferro and Matteo De Tommaso for recruiting participants and for the great support provided during this study. We also thank Courtney Goodridge for the English proofreading.

\section{References}

Antoine, S., \& Gevers, W. (2016). Beyond left and right: Automaticity and flexibility of number-space associations. Psychonomic Bulletin \& Review, 23(1), 148-155. doi:10.3758/s13423-015-0856-x

Dehaene, S., Bossini, S., \& Giraux, P. (1993). The mental representation of parity and number magnitude. Journal of Experimental Psychology: General, 122, 371-396. doi:10.1037/0096-3445.122.3.371

Frith, C. D., \& Frith, U. (1972). The solitaire illusion: An illusion of numerosity. Perception \& Psychophysics, 11(6), 409-410. doi:10.3758/BF03206279

Fumarola, A., Prpic, V., Da Pos, O., Murgia, M., Umiltà, C., \& Agostini, T. (2014). Automatic spatial association for luminance. Attention, Perception, \& Psychophysics, 76(3), 759765. doi:10.3758/s13414-013-0614-y 
Fumarola, A., Prpic, V., Fornasier, D., Sartoretto, F., Agostini, T., \& Umiltà, C. (2016). The spatial representation of angles. Perception, 45(11), 1320-1330. doi:10.1177/ 0301006616661915

Gevers, W., Reynvoet, B., \& Fias, W. (2003). The mental representation of ordinal sequences is spatially organized. Cognition, 87(3), B87-B95. doi:10.1016/S0010-0277(02)00234-2

Gevers, W., Santens, S., Dhooge, E., Chen, Q., Van den Bossche, L., Fias, W., \& Verguts, T. (2010). Verbal-spatial and visuospatial coding of number-space interactions. Journal of Experimental Psychology: General, 139(1), 180. doi:10.1037/a0017688

Gevers, W., Verguts, T., Reynvoet, B., Caessens, B., \& Fias, W. (2006). Numbers and space: A computational model of the SNARC effect. Journal of Experimental Psychology: Human Perception and Performance, 32, 32-44. doi:10.1037/0096-1523.32.1.32

Leth-Steensen, C., \& Citta, R. (2016). Bad-good constraints on a polarity correspondence account for the spatial-numerical association of response codes (SNARC) and markedness association of response codes (MARC) effects. The Quarterly Journal of Experimental Psychology, 69(3), 482-494. doi:10.1080/17470218.2015.1055283

Lidji, P., Kolinsky, R., Lochy, A., \& Morais, J. (2007). Spatial associations for musical stimuli: A piano in the head? Journal of Experimental Psychology: Human Perception \& Performance, 33, 1189-1207. doi:10.1037/0096-1523.33.5.1189

Notebaert, W., Gevers, W., Verguts, T., \& Fias, W. (2006). Shared spatial representations for numbers and space: The reversal of the SNARC and the Simon effects. Journal of Experimental Psychology: Human Perception and Performance, 32, 1197-1207. doi:10.1037/0096-1523.32.5.1197

Proctor, R. W., \& Cho, Y. S. (2006). Polarity correspondence: A general principle for performance of speeded binary classification tasks. Psychological Bulletin, 132, 416442. doi:10.1037/0033-2909.132.3.416

Prpic, V. (2017). Perceiving musical note values causes spatial shift of attention in musicians. Vision, 1(2), 16. doi:10.3390/vision1020016

Prpic, V., Fumarola, A., De Tommaso, M., Baldassi, G., \& Agostini, T. (2013). A SNARClike effect for music tempo. Review of Psychology, 20(1-2), 47-51.

Prpic, V., Fumarola, A., De Tommaso, M., Luccio, R., Murgia, M., \& Agostini, T. (2016). Separate mechanisms for magnitude and order processing in the spatial-numerical association of response codes (SNARC) effect: The strange case of musical note values. Journal of Experimental Psychology: Human Perception and Performance, 42(8), 1241. doi:10.1037/xhp0000217

Prpic, V., \& Luccio, R. (2016). Do you hear more piano or drum sounds? An auditory version of the solitaire illusion. Perception, 45(12), 1433-1438. doi:10.1177/ 0301006616672580

Prpic, V., Murgia, M., De Tommaso, M., Boschetti, G., Galmonte, A., \& Agostini, T. (2016). Octave bias in pitch perception: The influence of pitch height on pitch class identification. Perception, 45(9), 1060-1069. doi:10.1177/0301006616651953 
Ren, P., Nicholls, M. E. R., Ma, Y. Y., \& Chen, L. (2011). Size matters: Non-numerical magnitude affects the spatial coding of response. PLOS ONE, 6(8), e23553. doi:10.1371/ journal.pone.0023553

Restle, F. (1970). Speed of adding and comparing numbers. Journal of Experimental Psychology, 95, 437-444. doi:10.1037/h0028573

Rusconi, E., Kwan, B., Giordano, B. L., Umiltà, C., \& Butterworth, B. (2006). Spatial representation of pitch height: The SMARC effect. Cognition, 99, 113-129. doi:10.1016/j.cognition.2005.01.004

Santens, S., \& Gevers, W. (2008). The SNARC effect does not imply a mental number line. Cognition, 108, 263-270. doi:10.1016/j.cognition.2008.01.002

Santiago, J., \& Lakens, D. (2015). Can conceptual congruency effects between number, time, and space be accounted for by polarity correspondence? Acta Psychologica, 156, 179191. doi:10.1016/j.actpsy.2014.09.016

Timmers, R., \& Li, S. (2016). Representation of pitch in horizontal space and its dependence on musical and instrumental experience. Psychomusicology: Music, Mind, and Brain, 26(2), 139. doi:10.1037/pmu0000146

\title{
Linearna reprezentacija visine tona kod SMARC efekta
}

\begin{abstract}
Sažetak
Efekt se prostorno-glazbene povezanosti kodova za odgovor (engl. spatial-musical association of response codes - SMARC) odnosi na potvrđenu pojavu bržeg i točnijeg reagiranja na niske, odnosno visoke tonove kada se odgovor da u donjem ili lijevom, odnosno u gornjem ili desnom dijelu prostora. Ova pojava ima mnogo sličnosti s efektom prostorno-numeričke povezanosti kodova za odgovor (engl. spatial-numerical association of response codes - SNARC), koji je u mnogo većoj mjeri istražen i teorijski razmatran. Prva teorija koja je pokušala objasniti efekt SNARC pretpostavlja da se položaj broja na mentalnoj numeričkoj crti izravno preslikava na vanjski prostor u kojem izvršavamo motorni odgovor. Suprotno tome, kasnija objašnjenja pretpostavljaju da se brojevi automatski kategoriziraju u dvije suprotstavljene kategorije (npr. mali nasuprot veliki), a zatim se povezuju s alternativama za odgovor (lijevo nasuprot desno). Kako bi se razlučilo koja teorija bolje objašnjava efekt SNARC, napravljena je modifikacija zadatka u kojem se odgovor bliže/dalje u odnosu na referentnu tipku daje jednom rukom. Međutim, modificirani zadatak nikad nije primijenjen na visine tonova i dosad nije predloženo specifično teorijsko objašnjenje efekta SMARC. Suprotno su prethodnim istraživanjima $s$ brojevima naši rezultati više u skladu $s$ hipotezom o izravnom preslikavanju i upućuju na linearnu reprezentaciju visine tona te upućuju na zaključak da su efekti SNARC i SMARC u osnovi različiti fenomeni, pa samim time zahtijevaju i različito teorijsko objašnjenje.
\end{abstract}

Ključne riječi: SMARC, SNARC, visina tona, prostorna kompatibilnost odgovora, mentalna numerička crta 


\title{
Representación linear de la altura de tono en el efecto SMARC
}

\begin{abstract}
Resumen
El efecto de la asociación espacio-musical de códigos para la respuesta (inglés: SMARC) consiste en las respuestas más rápidas y más precisas a tonos bajos (vs. altos) cuando se realizan en el espacio de abajo/izquierda (vs. arriba/derecha). Este fenómeno tiene mucho en común con el efecto de la asociación espacio-numérica de códigos para la respuesta (inglés: SNARC) que en todo caso se ha investigado más exhaustivamente y discutido teoréticamente. La primera teoría que intentó explicar el efecto SNARC supuso que la posición del número en la línea numérica mental se refleja directamente al espacio exterior en el que se ejerce la respuesta. Al contrario, los intentos posteriores de explicar el efecto afirman que los números se categorizan automáticamente en dos categorías opuestas (p. ej. pequeño vs. grande) y luego se asocian con las alternativas de respuestas (izquierda vs. derecha). Para aclarecer cuál de las dos teorías opuestas explica mejor el efecto SNARC, se modificó la tarea en la que se responde con una mano si está más cerca o lejos de la clave de referencia. Sin embargo, esta tarea modificada nunca se ha aplicado a la altura de tonos y en este momento no hay explicaciones teoréticas específicas del efecto SMARC. El objetivo de este trabajo es llenar este hueco en nuestro saber. Al contrario de aquello que se comprobó para los números, nuestros resultados se asocian más con la hipótesis del reflejo directo e indican la representación linear de la altura de tono. Nuestros datos sugieren la posibilidad de que los efectos SNARC y SMARC tengan un origen diferente y requieran diferentes explicaciones teoréticas.
\end{abstract}

Palabras clave: SMARC, SNARC, altura de tono, compatibilidad de respuesta espacial, línea de números mental

Primljeno: 30.08.2017. 